\title{
Estimation of energy expenditure in people with physical impairments
}

\author{
Keiko Motonaga \\ 国立スポーツ科学センター，７115-0056 東京都北区西が丘3-15-1 (Japan Institute of Sports Sciences, 3-15-1 Nishigaoka, \\ Kita-ku, Tokyo 115-0056, Japan)
}

Received: June 11, 2018 / Accepted: July 30, 2018

\begin{abstract}
The scarce evidence on dietary reference intakes (DRIs) for people with physical impairments has made estimation of total energy expenditure (TEE) and nutritional requirements difficult. The first reason for this difficulty is that estimating basal metabolic rate (BMR) or resting energy expenditure (REE) is challenging. The second reason is the difficulty of estimating body composition, which is useful for calculating BMR, and the third reason is the difficulty of estimating physical activity level. The reason for all these difficulties is that DRIs applies to all types of physical disabilities. Thus, it turns out to be unenviable for planning nutritional programs and evaluating physical impairments. However, notable references are available on energy requirements not only for the corresponding health maintenance and promotional information for preventing physical impairments caused by lifestyle diseases in middle and old age but also for improving performance of Paralympic athletes. This review article focuses on the estimation of the energy requirements for people with physical impairments and discusses the possibilities and limitations of methods.
\end{abstract}

Jpn J Phys Fitness Sports Med, 67(5): 365-371 (2018)

Keywords : physical impairments, estimating energy requirements, basal metabolic rate, physical activity level

\section{はじめに}

東京オリンピック・パラリンピック競技大会が2020年 に開催されることになって以降, メディアで取り上げら れる障がい者アスリートのニュースや番組, 記事の数は 格段に増加した。 スポーツ基本計画でも，健常者だけで なく障がい者の健康維持のために運動が有用であること が示され，実施者の増加が目標に挙げられている1).

健康の維持増進のために必要な要素は栄養・運動・休 養であるのは周知の事実である。栄養では，「何をどれ だけ食べればよいか」ということがポイントとなる。病 院や学校, 福祉施設やスポーツの現場で, 患者や利用者, 選手といった対象者のために栄養計画を立案する際に， 管理栄養士や公認スポーツ栄養士が優先的に検討する項 目の 1 つが, 推定エネルギー必要量 (Estimated energy requirement: EER）の設定である.

エネルギーはいわゆる栄養素とは異なりその重量を計 量することはできないが,「各種栄養素の必要量設定に 大きな影響を及ぼす ${ }^{2)}$. Atwaterのエネルギー換算係数 では三大栄養素と呼ばれるたんぱく質, 脂質, 炭水化物

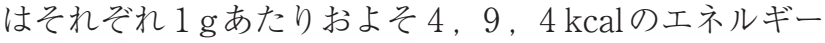
を産生する ${ }^{2)}$. エネルギー産生栄養素バランスはこれら の構成成分が総エネルギー摂取量に占める割合であり, これら栄養素の構成比率を指標として, 三大栄養素の摂 取不足の回避だけでなく, 生活習慣病の発症予防とその 重症化予防に役立てられる。そのため三大栄養素の必要 量を設定する際には，体重あたりの栄養素必要量だけで なく, EERとエネルギー産生栄養素バランスが考慮さ れる。また「日本人の食事摂取基準（2015年版）」にお いてビタミン $\mathrm{B}_{1}$, ビタミン $\mathrm{B}_{2}$, ナイアシンの必要量は, エネルギー $1000 \mathrm{kcal}$ あたりで設定されている2)。すなわ ちこの 3 つの栄養素の必要量はエネルギー必要量に係数 を乗じることで算出される，以上のことから， EERを設 定することは他の栄養素の必要量を設定するためにも重 要である。

一方で障がい者のEERの設定を行う場合，その障がい の特性上，健常者の值や式をそのまま用いると過大また は過小評価となる可能性があるが，その詳細は不明であ る。そこで今回，身体障がい者のうち，特に肢体不自由 者に着目してエネルギー代謝に関する知見を整理し，課 
題について検討したい.

\section{障がいとは}

法律での定義は，平成23年に改定された「障害者基本 法」3)によると,「身体障害, 知的障害又は精神障害があ るため, 継続的に日常生活又は社会生活に相当な制限を 受ける者をいう.」とされている (法律や医療現場では「障 害」と表記される)。また平成25年制定の「障害者総合 支援法」では，障がいを有する者（難病患者を含む）の うち, 18歳以上を障害者, 18歳未満は障害児としている ${ }^{4}$.

一般に「三障害」は「身体, 知的, 精神」の三つの障 がいを指す ${ }^{5)}$. 障がいの大まかな概要は Fig. $1^{5)}$ に示すと おりで, 視覚障がいや聴覚障がいは身体障がいの 1 つで ある5).

障がい者のうち, 特にエネルギー必要量を推定する上 で配慮が必要と考えられるのは肢体不自由である，重複 障がいでない場合, 視覚, 聴覚, 知的, 精神の各障がい に拈いては，一般には歩行をはじめとする身体活動は 健常者と同様に行うことが可能であるため, 基礎代謝 量 (Basal metabolic rate: BMR) または安静時代謝量 (Resting energy expenditure: REE) も「日本人の食事 摂取基準 (2015年版) 」) の健常者の方法に則って推定し ても問題ないと考えられる.

\section{肢体不自由の種類と原因疾患}

肢体不自由と一言で言ってもその種類および障がい要 因はさらに多岐にわたる，全国障害者スポーツ大会の陸 上競技で用いられる障がい区分ではTable 1のように, 特に競技特性にあわせた区分となっている ${ }^{6)}$ ，陸上競技 に扮いて，上肢，下肢，体幹に障がいのある選手は義手， 義足，杖など装具などを用いる，あるいは何も使用せず
に立位姿勢にて競技を行うことが多い6)，座位姿勢で陸 上競技を行う選手に多い障がいとして脊髄損傷や脳原生 まひなどがあるが，中には両下肢切断者でも，義足で立 位の種目を行うのではなく車いす競技を行う者も少なく ない，陸上競技以外でも，例えば車いすバスケットボー ルやシッティングバレーでは，その競技特性から障がい 種別に関わらずすべての競技者は座位姿勢で競技を行っ ている.

障がいの区分として，障がい要因からみた障がい区分 とは別に，運動障がい（まひ）の分類によるものもあ る。代表的なまひとして，両下肢のまひである対まひ (paraplegia)，両上下肢のまひである四肢まひ（tetraplegia/quadriplegia)，四肢まひであるが下肢の障がいが比 較的軽い両まひ (diplegia) などがある。このまひにも完 全と不完全とがあり，不完全まひの場合，日常生活で短 い距離であれば二足歩行が可能な脊髄損傷者や脳性まひ 者もいる，以下に，代表的な肢体不自由の原因疾患につ いて述べる.

脊㵦損傷（Spinal Cord Injury：SCI） 脊髄損傷とは，脊 柱に強い外力が加えられた結果，脊椎が破壊され脊䯣が 損傷をうける病態である7 ${ }^{7}$. 運動障がいとしては顤髄損 傷では四肢麻瘏となり, 胸髄あるいは腰髄損傷では対麻 痺となる ${ }^{7)}$.

脳性まひ（Cerebral Palsy：CP）日本に扔ける脳性麻 疩の定義は「受胎から生後 4 週間までに生じた脳の障害 によって扔こる，運動及び姿勢や片側上下肢のみが障が いの片まひ（hemiplegia）, 対まひ，四肢まひ，両まひ， 重複片まひ（double hemiplegia, 四肢まひであるが下肢 の障がいが比較的軽い) に分類される ${ }^{7}$.

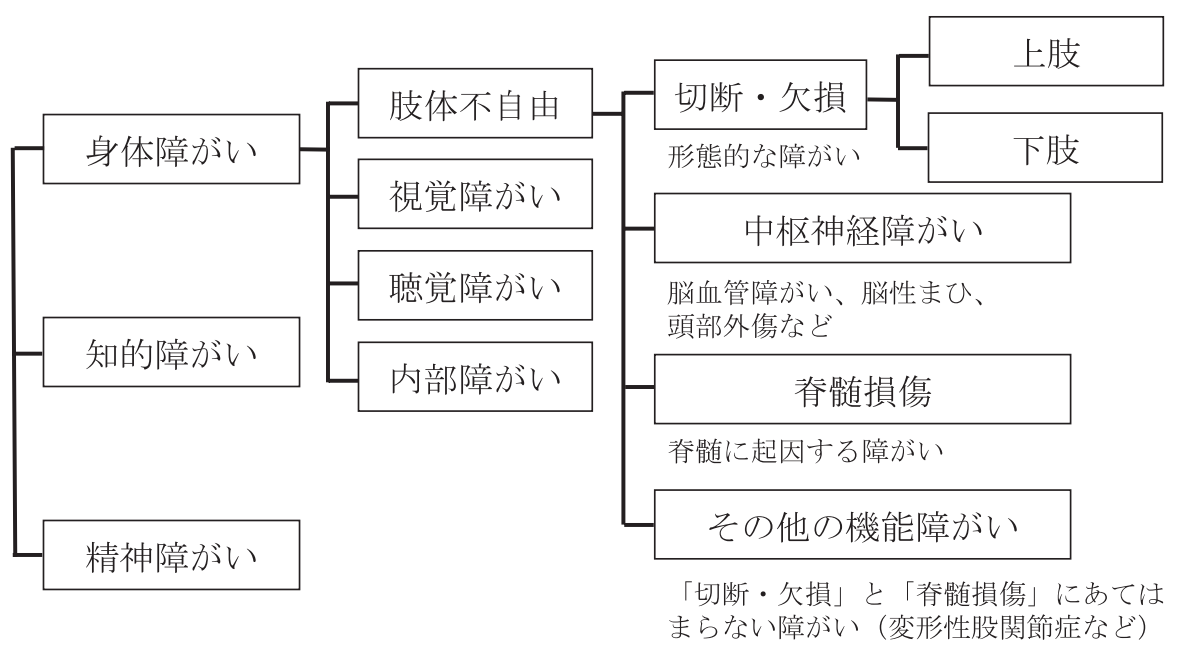

Fig. 1 Summary of types of disabilities (ref. 5) 
Table 1. Classification of cripple types (ref. 6)

\begin{tabular}{|c|c|c|}
\hline \multicolumn{2}{|l|}{ 障害 } & 疾患の例 \\
\hline \multirow{3}{*}{$\begin{array}{l}\text { 切断 · } \\
\text { 機能障害 } \\
\text { (立位) }\end{array}$} & 上肢 & $\begin{array}{l}\text { 先天性欠損症、先天性奇形、切断（事故や疾病による）、 } \\
\text { 腕神経叢まひ、脊髄性小児まひ（ポリオ）、分婏まひ }\end{array}$ \\
\hline & 下肢 & 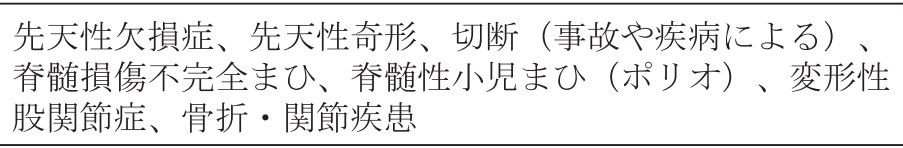 \\
\hline & 体幹 & 先天性側弯症、脊椎カリエス、脊柱管狭窄症 \\
\hline \multicolumn{2}{|c|}{$\begin{array}{l}\text { 脳血管障害・ } \\
\text { 脳性まひ等 } \\
\text { (脳原生まひ) }\end{array}$} & 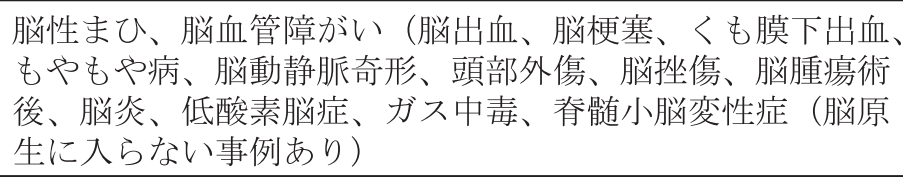 \\
\hline \multicolumn{2}{|c|}{$\begin{array}{l}\text { 脊髄損傷等 } \\
\text { (脳原ま生ま以外 } \\
\text { で車い寸使用) }\end{array}$} & 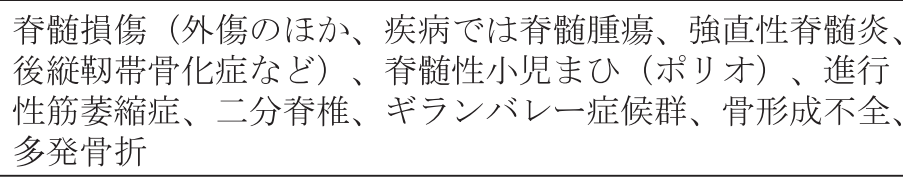 \\
\hline \multicolumn{2}{|l|}{ その他 } & 筋ジストロフィー、重症筋無力症など \\
\hline
\end{tabular}

急性灰白髄炎 (Poliomyelitis) / ポリオ (Polio) ポリオは, ポリオウィルスが口を介して腸で感染する。多くの場 合は感染しても明らかな症状は現れず免疫ができるが, ウィルスが腸管から春髄に入ると手や足に左右非対称性 の弛緩性まひが現れる。

切断・欠損 (Amputee) (四肢) 切断とは, 四肢の一部 が何らかの原因により体から切り離された状態を指す ${ }^{8)}$. 原因は事故などの外傷による損傷が多いが，悪性腫瘍や 代謝性疾患（糖尿病, 動脈硬化など）による血行障害か ら四肢末梢が壊死となり医師の診断で切断がなされるこ ともある。身体障害者手帳では「欠損」という表現が用 いられている9).

切断・午損部位により上肢・下肢に分類され, さらに どの部位の切断・欠損であるかにより細かく分類される. 切断部位によっては関節拘縮を引き起こすことがある。

\section{脳血管障害 (Cerebral Vascular Disease)/脳卒中} (Stroke) 脳血管障害とは, 脳血管の何らかの変化によ り, 脳に一過性ないし持続性の虚血（梗塞）または出血 が生じたものをいう ${ }^{8)}$. NINDS- III分類により 4 つに分 類され，脳卒中もその中に含まれる。脳卒中には脳梗塞 (Brain Infraction), 脳出血 (Brain Hemorrhage), く も膜下出血 (Subarachnoid Hemorrhage), 動静脈奇形 (Arteriovenous Malformation: AVM) の病型があり, 脳 梗塞はさらにアテローム血栓性, 心塞栓性, ラクナ, そ の他に分類される ${ }^{8)}$. 脳血管障害によってみられるのは 運動機能, 感覚機能, 知的機能, 情動, 高次脳機能障が いなどである。通常は片まひであり，不随意運動や足部 の内反・尖足歩行がみられる場合もある.

\section{肢体不自由者のEERを推定する上での課題}

EERの推定式で代表的なものは「BMR × 身体活動レ ベル (Physical activity level: PAL)」である2). しかし 基礎代謝基準值や Ganpule et al.の式 ${ }^{10)}$ など「日本人の 食事摂取基準 (2015年版)」で示されている BMRの推定 式は健常者のデー夕に基ついたものであり, 肢体不自由 者が活用することについては想定されていない22．障が い者のBMR推定には, 以前は障がいの程度に合わせて 健常者よりも低く見積もる「係数」が示されていたよう であるが11)，現在ではそれがどのようなエビデンスを以 て設定されたのか, その根拠を確認するには情報が不十 分である、金谷と石田 ${ }^{12)}$ は，障害者支援施設において実 際の食事摂取量と照合した結果，食事摂取基準の活用が 必ずしも適切ではないとしている。またPALについて も，「日本人の食事摂取基準（2015年版）」では肢体不自 由者への適用については言及されていない2）。

同様に, 行動記録からメッツ值 (metabolic equivalent: METs, 座位安静時謝量の倍数として表した各身体活動 の強度の指標 ${ }^{2)}$ を活用してEERを設定しようとして も, 肢体不自由者では不自由な部位や程度によって個人 差が大きく, 健常者で用いられる BMRを 1.1 倍する方法 やMETsを活用する方法ではEERの推定が困難である.

もちろん, 摂取エネルギーの過不足の指標である体重 をモニタリングすることで, ある程度の評価することは 可能である. しかしEERの設定に至るには数日の食事記 録の分析によるエネルギー摂取量の算出が必要となる. さらに本来, どの食事アセスメント法を用いても $15 \%$ 程 度の過小評価の可能性があることを忘れてはならない2). 


\section{肢体不自由者のエネルギー代謝に関する報告}

エネルギー代謝の研究では, 事例数の少なさから, 例 えば脊髄損傷や脳性まひ，切断などを重度から軽度まで 障がいレベルも考慮せずにまとめて「車いす利用者」と 扱うなど，複数の障がい要因をまとめて報告している研 究も少なくない ${ }^{13,14)}$. しかしながらそれぞれの障がい要 因がエネルギー代謝に与える影響は異なっている。全て を網羅することはできないが，代表的な肢体不自由の原 因疾患ごとのエネルギー代謝研究について紹介する。

脊髄損傷 肢体不自由者のうち, 最もエネルギー代謝の 研究報告が多いのは脊髄損傷であり，これまでBuchholz and Pencharz ${ }^{8)}$, Price ${ }^{15)}$, Nevin et al. ${ }^{16)}$ らによってエ ネルギー代謝に関するレビューが作成されている。脊髄 損傷は完全まひと不完全まひとがあり，損傷部位の高 度になるほど障がいの程度が重くなる。 Buchholz and Pencharz ${ }^{8)}$ によると慢性期の脊髄損傷者（およそ四肢ま ひ）のREEの実測值を健常者のものと比べた場合に 14 〜 $27 \%$ 低かったと報告している。健常者よりも REEが 低い要因として，脊髄損傷者は特に下肢の除脂肪量が少 ないことと，交感神経系活動の異常が考えられる ${ }^{8)}$ 。一 方で実測したREEを体組成（除脂肪量など）で標準化 すると，健常者との差はないとされ，食事誘発性体熱産 生も健常者と同様であるとされている ${ }^{8)}$.

脳性まひ 脳性まひは, その疾患の特徵からエネルギー 代謝の報告の多くは子供が対象とされている。 Johnson et al. ${ }^{17)}$ は成人 (平均年齢が男女とも30代) を対象に DXA やDLW で調査を行い，REEは男性で $1611 \pm 293$ $\mathrm{kcal} / \mathrm{day}$ ，女性で1363土213 kcal/dayであったことを報 告している。一方で, 成人脳性まひ者の身体活動内容が 個人間で異なる結果, TEEの值もばらばらであったこと, 障がいにより歩行の可否が異なるが, それがTEEの推定 に大きな影響を及ぼすこと，またTEEに占める RMRの 割合も歩行の可否により異なっていることが示された ${ }^{17)}$.

Claridge et al. ${ }^{18)}$ は，脳性まひの重症度の分類尺度で ある粗大運動機能評価システム (Gross Motor Function Classification System: GMFCS）を用いて対象を $5 つ に$ 分類し, 制限なしに歩行できるレベル 1 と, 補助具を用 いても自力での移動が難しいレベル 5 で活動時間を比較 したところ，座位活動時間はレベル 5 が長く，身体活動 時間はレベル 1 が長かったことを報告しており，これら もエネルギー代謝に影響すると考えられる。

急性灰白髄炎 脳性まひと同様，若年で発症する場合が 多いが，エネルギー代謝の研究では中年以降に発症する ポリオ後症候群を対象としたものや，膝から足にかけて
の装具を用いて歩行する場合のエネルギー消費量を調査 したものが多い. Bargieri et al. ${ }^{19)}$ は間接熱量計で測定 したBMRをDXAにより得られた体組成データから分

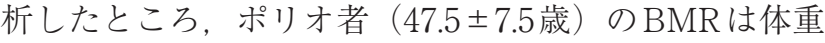
や除脂肪体重あたりにすると同年歯のコントロール群 (41.6 \pm 10.8 歳) のものと差がなかったと報告している. またDavis et $\mathrm{al}^{20)}$ は補助具を装着した場合の歩行による エネルギー消費量は健常者の歩行のものと変わらないと している.

切断・欠損 切断者に関するエネルギー代謝の研究では, 各種義足を装着して歩行した際のエネルギー消費量を検 討したものが多いようである。 Gailey et al. ${ }^{21)} の$ 報告で は, 脛骨以上の切断者において, 健常者と比較した際に 2 ポンド $(907 \mathrm{~g})$ までの重量の義足を装着した歩行は代 謝に影響がないとしている。切断部位（割合）がBMRや REEに及ぼす影響に関するエビデンスは十分ではない が，二重エネルギーX線吸収測定法（Dual-energy $\mathrm{x}^{-}$ ray absorptiometry：DXA）による体組成評価が可能で あればCunninghamの式により REEが評価できるという 報告もある ${ }^{22)}$.

脳血管障害/脳卒中 脳血管障害を対象とした報告は少 なく, Nagano et al. ${ }^{23)}$ は脳梗塞の急性期の REE 量が796 〜1637 kcalであったことを報告しているが，対象者30 名の平均年齢は79.5歳と非常に高齢である。

\section{各種推定式による BMR・REEの算出値と 間接熱量計による実測値の比較}

Bargieri et al. ${ }^{19)}$ はポリオを対象に間接熱量計で 測定したBMRはHarris-Benedict式で求めた推定值 より $10 \%$ 低かったと報告している。Buchholz and Pencharz $^{8)}$ によると慢性期の脊髄損傷者（およそ四肢ま ひ）で, Harris-Benedictなどの推定式を用いて算出し たBMRよりも，実測值では 5〜32\%低かった。Nagano et al. ${ }^{23)}$ が脳梗塞（脳卒中）者を対象に行った研究で は, Harris-Benedict, Cunningham, Owen, Mifflin, Wang と日本人の簡易式（Otani）を用いてBMRを推定 した結果, Harris-Benedict式が実測值に最も近かった

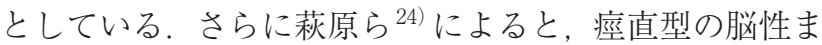
ひの基礎代謝基準值は，健常者よりも1.3〜1.9倍高いこ

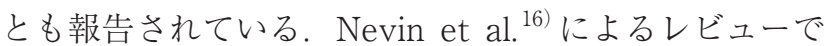
は, 脊髄損傷者を対象とした先行研究より各種推定式と $\mathrm{BMR} \cdot \mathrm{RMR}$ の実測值との比較に関するまとめを行い, Harris-Benedict式では30\%以上高い過大評価を示した 研究がある一方，あまりに代謝の低い対象者の研究では 推定值と実測值に差がなかったと報告している。そのた め彼らは推定式を用いることを現状では「つかみどころ 
がない」とし，なるべく実測することを進めている ${ }^{16)}$.

アスリートを対象とした調査では，まずJuzwiak et al. ${ }^{13)}$ が，ブラジルのパラリンピック陸上競技選手（視覚 障がい, 下肢欠損, 脳性まひ）のBMR実測值を HarrisBenedict, Cunningham, Owen, FAO/OMS, ブラジル の食事摂取基準, Mifflinの式で得た推定值と比較し, この対象者ではOwen と Mifflinの式が最も実測值に近 かったと報告している。またPelly et al. ${ }^{25)}$ は男性脊髄 損傷選手のREEを測定し, Harris-Benedict, Cunningham, Schofield, Owen, Mifflinの各種式から得た推定值 との比較を行った。その結果, 実測值と比べてOwenの 式以外では有意差はなかったが，実測值との有意な相関 もみられず，脊髄損傷アスリート用に修正が必要である とした。

\section{肢体不自由者のBMRおよびREE推定に影響する因子}

Scaramella et al. ${ }^{26)}$ によると, 代謝やエネルギー消費 量減少の因子として脊髄損傷や下部位の脳性まひ, 両下 肢切断を挙げ, それらは筋肉量の減少の因子ともなり得 るとされているが，詳細な検討を行ったエビデンスはま だあまりみられない。また例えば同じ春髄損傷という障 害のカテゴリに区分される疾患であっても, 胸髄損傷と 比べて頝髄損傷では一般的に体重や除脂肪量が少ないな ど，その障がいレベルにより体重や体脂肪量, 除脂肪量 の個人差が大きくなることが考えられる. Table 2 には, 肢体不自由者のエネルギー代謝量推定に影響する要因を まとめたが，いくつもの影響因子があることがわかる。

健常者の推定式が肢体不自由者にとって扱いにくい 理由の 1 つに除脂肪量の推定が挙げられる。 Owenや Wang, Cunninghamらの推定式は除脂肪量を用いてい
るが，その推定を皮脂厚法で行うか（Juzwiak et al.) ${ }^{13)}$ かDXA で行うか (Pelly et al.) ${ }^{25)}$ インピーダンスを用い るか (Nagano et al. $)^{23)} に よ り$ 同一対象者でも算出され る除脂肪量が異なり， BMRおよびREEを算出する際に 誤差を大きくする一因となっている。

以上のような背景から，現状では，肢体不自由者の BMRおよびREEの推定には，計測方法によって值が異 なる除脂肪量を用いた推定式を用いるよりも，身長，体 重, 性別, 年齢を係数としたHarris-Benedictや Mifflin の方がより実測值に近くなる可能性がある。日本人の肢 体不自由者では，日本人を対象としてこの 4 つの因子を もとに作成されたGanpule et al. ${ }^{10)}$ の式が扱いやすいと 考えられるが，それをゴールドスタンダードとして扱う には時期尚早である.

肢体不自由者のPALの設定 前述のように「日本人の食 事摂取基準 (2015年版)」 ${ }^{2)}$ には肢体不自由者のPAL設定 に関する記述はない. 内山ら ${ }^{27)}$ は先行研究をもとにリハ ビリテーション期の脊髄損傷者のPALを 1.4 , リハビリ テーションを実施していない場合にはPALを 1.2 と仮定 し，1 か月後の体重変化と, EERとエネルギー摂取量と の差から予測した体重の変化からその值が適切であった と推察している.稲山ら ${ }^{28)}$ は在宅脊髄損傷者の PALを 1.5 と設定し，身体活動レベルのアセスメントも重要である としている. Motonaga et al. ${ }^{29)}$ が陸上競技T54クラスの 脊髄損傷者を対象に二重標識水法で得た総エネルギー消 費量と BMRから算出したPALでは2.0を超えるケースも みられ, 肢体不自由であっても活動的な対象者の場合に は健常者と同様のPAL值とするのが良いと考えられる。 肢体不自由者の総エネルギー消費量推定に関する研究

Table 2. Influential factors for estimating energy expenditures in physical impairments

\begin{tabular}{|c|c|}
\hline 項目 & 考慮すべき点 \\
\hline $\begin{array}{l}\text { 障がい部位が上肢か下肢か体幹か、 } \\
\text { 欠損や障がいの程度はどうか }\end{array}$ & $\begin{array}{l}\text { 体幹や下肢など筋肉量が多い部位で、切断および機能 } \\
\text { 不全があると筋肉量が少なくなる。 }\end{array}$ \\
\hline 脊髄の障がい部位が下位か上位か & $\begin{array}{l}\text { 脊髄損傷や脳性麻痺などは障がい部位が上位・重度に } \\
\text { なるほど動かせる部位が少なくなり、筋肉量が少なく } \\
\text { なる。 }\end{array}$ \\
\hline まひが完全か不完全か & $\begin{array}{l}\text { 不完全まひの場合、日常生活は歩行する場合もあり、 } \\
\text { 一般に完全まひより筋肉量が多い。 }\end{array}$ \\
\hline 痤性があるかどうか & $\begin{array}{l}\text { 痤性がある場合、不随意運動に伴う筋肥大がみられ、 } \\
\text { 代謝も高くなる。 }\end{array}$ \\
\hline 日常生活が立位か車いすか & \multirow{2}{*}{$\begin{array}{l}\text { 身体活動時に下肢を使用する方が下肢の筋肉量が多く } \\
\text { なる。また日常的な移動手段が車いすである場合、下 } \\
\text { 肢の笳肉量が少ない傾向にある。 }\end{array}$} \\
\hline 競技時に立位か車いすか & \\
\hline 自走車いすか電動車いすか & $\begin{array}{l}\text { 自走であれば上肢の筋肥大が見込まれるが、電動であ } \\
\text { れば筋肉量は少なくなる。 }\end{array}$ \\
\hline
\end{tabular}


については, 加速度計を用いる方法 ${ }^{30)}$ やCollins et al. ${ }^{31)}$ による脊髄損傷レベルごとの METsの検討や，心拍数と の関係，行動記録による推定も実施されている，今後こ れら汎用性の高い手法が確立すれば，肢体不自由者の PALに関するさらなるエビデンスが得られると期待さ れる.

\section{おわりに}

これまで肢体不自由者をはじめとする障がい者のエネ ルギー代謝に関するエビデンスは非常に少なかった。し かしながら近年, パラリンピックに出場する障がい者の 活躍も後押ししてか世界的に障がい者や障がい者アス リートを対象とした報告が増えている。中高年者の生活 習慣病を起因とした中途障がいへの健康維持・増進の目 的だけでなく，障がい者アスリートの競技力向上のため の栄養戦略を立案するためにも, EERの設定は重要であ る. BMRおよびREEの推定式, 体組成推定方法, PAL の設定の大きく 3 つに関する知見が今後さらに深まれ ば，肢体不自由者の EER 設定がより容易になると期待 される。

利益相反自己申告：申告すべきものはなし

\section{参考文献}

1）スポーツ庁. 第 2 期スポーツ基本計画. http://www. mext.go.jp/sports/b_menu/sports/mcatetop01/ list/1372413.htm（アクセス日：2018年 6 月 9 日）

2）佐々木 敏, 菱田 明. 日本人の食事摂取基準 2015年版, 第 一出版, 東京, 2014.

3）内閣府. 障害者基本法. http://www8.cao.go.jp/shougai/ suishin/kihonhou/s45-84.html（アクセス日：2018年 6 月 9 日）

4）厚生労働省. 障害者自立支援法. http://www.mhlw. go.jp/topics/2005/02/tp0214-1.html（アクセス日：2018 年 6 月 9 日)

5）大久保春美. 第 2 編 障害者スポーツの理念と指導法, 第 1 章障がい者スポーツの意義と理念, 障がい者スポー ツ指導教本 初級・中級く改訂版>, 日本障がい者スポー ツ協会編, ぎょうせい, 東京, 23-26, 2012.

6）大久保春美. 第 2 編 障害者スポーツの理念と指導法, 第 3 章指導上の留意点, 障がい者スポーツ指導教本 初級・ 中級 <改訂版〉, 日本障がい者スポーツ協会編, ぎょう せい, 東京, 34-35, 2012

7）草野修輔. 第 4 編 身体と障害, 第 2 章障害各論, 障がい 者スポーツ指導教本 初級・中級《改訂版>, 日本障が い者スポーツ協会編, ぎょうせい, 東京, 129-139, 2012.

8) Buchholz AC, Pencharz PB. Energy expenditure in chronic spinal cord injury. Curr Opin Clin Nutr Metab Care 7: 635-639, 2004.

9）厚生労働省. 身体障害者障害程度等等級表. http://www. mhlw.go.jp/bunya/shougaihoken/shougaishatechou/ dl/toukyu.pdf（アクセス日：2018年 6 月 9 日）
10) Ganpule AA, Tanaka S, Ishikawa-Takata K, Tabata I. Interindividual variability in sleeping metabolic rate in Japanese subjects. Eur J Clin Nutr 61: 1256-1261, 2007. doi: 10.1038/sj.ejcn.1602645.

11）大和田浩子. III実践編 障害者施設に扔ける活用, 日本人 の食事掑取基準（2005年版）の活用, 山本 茂, 由田克士 編, 第一出版, 東京, 72-74, 2005.

12）金谷由希, 石田裕美：障害者支援施設に扔ける「日本人 の食事摂取基準」の活用に関する基礎的検討, 栄養学雑 誌, 68: 104-109, 2010. doi: 10.5264/eiyogakuzashi.68.104.

13) Juzwiak CR, Winckler C, Joaquim DP, Silva A, de Mello MT. Comparison of measured and predictive values of basal metabolic rate in Brazilian paralympic track \& field athletes. Int J Sport Nutr Exerc Metab 26: 330-337, 2016. doi: 10.1123/ijsnem.2015-0015.

14) Knechtle B, Köpfli $W$. Treadmill exercise testing with increasing inclination as exercise protocol for wheelchair athletes. Spinal Cord 39: 633-636, 2001. doi: 10.1038/sj.sc.3101229.

15) Price M. Energy expenditure and metabolism during exercise in persons with a spinal cord injury. Sports Med 40: 681-696, 2010. doi: 10.2165/11531960000000000-00000.

16) Nevin AN, Steenson J, Vivanti A, Hickman IJ. Investigation of measured and predicted resting energy needs in adults after spinal cord injury: a systematic review. Spinal Cord 54: 248-253, 2016. doi: 10.1038/ sc.2015.193.

17) Johnson RK, Hildreth HG, Contompasis SH, Goran MI. Total energy expenditure in adults with cerebral palsy as assessed by doubly labeled water. J Am Diet Assoc 97: 966-970, 1997.

18) Claridge EA, McPhee PG, Timmons BW, Martin Ginis KA, Macdonald MJ, Gorter JW. Quantification of Physical Activity and Sedentary Time in Adults with Cerebral Palsy. Med Sci Sports Exerc 47: 1719-1726, 2015. doi: 10.1249/MSS.0000000000000589.

19) Bargieri JV, Quadros AA, Pereira RD, Oliveira AJ, Lazaretti-Castro M, Silva AC. Basal metabolic rate and body composition in patients with post-polio syndrome. Ann Nutr Metab 53: 199-204, 2008. doi: 10.1159/000178156.

20) Davis PC, Bach TM, Pereira DM. The effect of stance control orthoses on gait characteristics and energy expenditure in knee-ankle-foot orthosis users. Prosthet Orthot Int 34: 206-215, 2010. doi: 10.3109/03093641003773189.

21) Gailey RS, Nash MS, Atchley TA, Zilmer RM, MolineLittle GR, Morris-Cresswell N, Siebert LI. The effects of prosthesis mass on metabolic cost of ambulation in non-vascular trans-tibial amputees. Prosthet Orthot Int 21: 9-16, 1997. doi: 10.3109/03093649709164525.

22) Elizabeth Broad, Chapter25, Special needs: the Paralympic athlete, Clinical Sports Nutrition $5^{\text {th }}$ edition, Louise Burke, Vicki Deakin, McGraw-Hill Education, AUS, 707-729, 2015.

23) Nagano A, Yamada Y, Miyake H, Domen K, Koyama T. 
Comparisons of predictive equations for resting energy expenditure in patients with cerebral infarct during acute care. J Stroke Cerebrovasc Dis 24: 1879-1885, 2015. doi: 10.1016/j.jstrokecerebrovasdis.2015.04.029.

24）萩原大介, 尾立純子, 佐伯孝子, 羽生大記, 湯浅（小島） 明子, 湯浅 (松井) 勲：身体障害者における推定エネル ギー必要量について, 生活科学研究誌, 6: 1-5, 2007.

25) Pelly FE, Broad EM, Stuart N, Holmes MA. Resting energy expenditure in male athletes with a spinal cord injury. J Spinal Cord Med 41: 208-215, 2018. doi: 10.1080/10790268.2017.1317060.

26) Scaramella J, Kirihennedige N, Broad E. Key nutritional strategies to optimize performance in para athletes. Phys Med Rehabil Clin N Am 29: 283-298, 2018. doi: 10.1016/j.pmr.2018.01.005.

27）内山久子, 角田伸代, 横瀬道絵, 佐久間 肇, 繁田文子, 岡 純, 稲山貴代, 加園恵三 : 脊髄損傷者の栄養 - 食事計画 における安静時代謝量測定意義の検討, 日本栄養士会雑 誌, 53: 911-918, 2010. doi: 10.11379/jjda.53.911.

28）稲山貴代, 横瀬道絵, 角田伸代, 内山久子, 佐久間 肇, 樋
口幸治, 岡 純, 加園恵三 : 推定方法の違いによる在宅 の脊髄損傷者の推定エネルギー必要量についての検討, 栄養学雑誌, 71: 59-66, 2013. doi: 10.5264/eiyogakuzashi.71.59.

29) Motonaga K, Hakamada N, Kondo E, Yoshino M, Kamei A, Shimizu K, Shimizu J, Oishi M, Suzuki A, Yamada Y, Hangai M, Ishige Y. Total energy expenditure of spinal cord injured athletes measured by Doubly Labeled Water method. J Phys Fitness Sports Med 6: 463, 2017.

30) Takigawa R, Inayama T, Yamada K, Muraoka Y, Ohkawara K. Assessment of daily physical activities with sensors attached to the upper limbs in healthy adults using a manual wheelchair. J Phys Fitness Sports Med 7: 193-202, 2018. doi: 10.7600/jpfsm.7.193.

31) Collins EG, Gater D, Kiratli J, Butler J, Hanson K, Langbein WE. Energy cost of physical activities in persons with spinal cord injury. Med Sci Sports Exerc 42: 691-700, 2010. doi: 10.1249/MSS.0b013e3181bb902f. 